$\begin{aligned} & \text { Valley life } \\ & \text { Climate model offers } \\ & \text { California a taste of } \\ & \text { things to come } \\ & \text { p818 }\end{aligned} \quad \begin{aligned} & \text { Seeing red } \\ & \text { Marine scientists } \\ & \text { bid to halt ocean } \\ & \text { acidification } \\ & \text { p820 }\end{aligned}$

\title{
Biologists fear cloning hype will undermine stem-cell research
}

\section{Jonathan Knight}

A dose of reality needs to be injected into the excitement surrounding therapeutic cloning, senior stem-cell biologists have warned.

Researchers fear that optimism generated by recent advances, including the award on 11 August of the first UK licence for research on the technique, has raised expectations of individualized cures for degenerative diseases. In reality, say those in the field, such a prospect remains distant at best.

"If we keep talking about cures and they don't come in the next few years, that's going to be a problem," says Jose Cibelli, a stem-cell researcher at Michigan State University in East Lansing.

The decision by the Human Fertilisation and Embryology Authority to grant a licence to the Newcastle Fertility Centre, part of the city's Life biotechnology village, triggered a storm of media attention. The licence allows scientists to create human embryos by inserting nuclei from human skin cells into human eggs. The Newcastle team will then be able to extract stem cells from the cloned embryo.

Although researchers such as Cibelli were thrilled at the news, some worry that the media coverage underplays just how few labs are working on therapeutic cloning. They also say that short-term benefits of the work, such as providing fresh insight into diseases such as diabetes and Parkinson's (see Nature 422, 787; 2003), are not acknowledged.

Short-term and long-term benefits are usually mentioned in the same breath, but the possibility of cures seems to overshadow the research benefits, says Lawrence Goldstein, a stem-cell researcher at the University of California, San Diego. "Many of us in the scientific community talk about both of these, but the press often seizes on one, as do the public and the patient advocates," he says.

Talk of cures is justified, say experts, but only in the long term. Researchers believe that embryonic stem cells can be coaxed to form any tissue in the body. So if they can be extracted from embryos cloned from a patient, they could be used as genetically identical replacements for damaged tissue. This would avoid the risk of rejection associated with transplants.

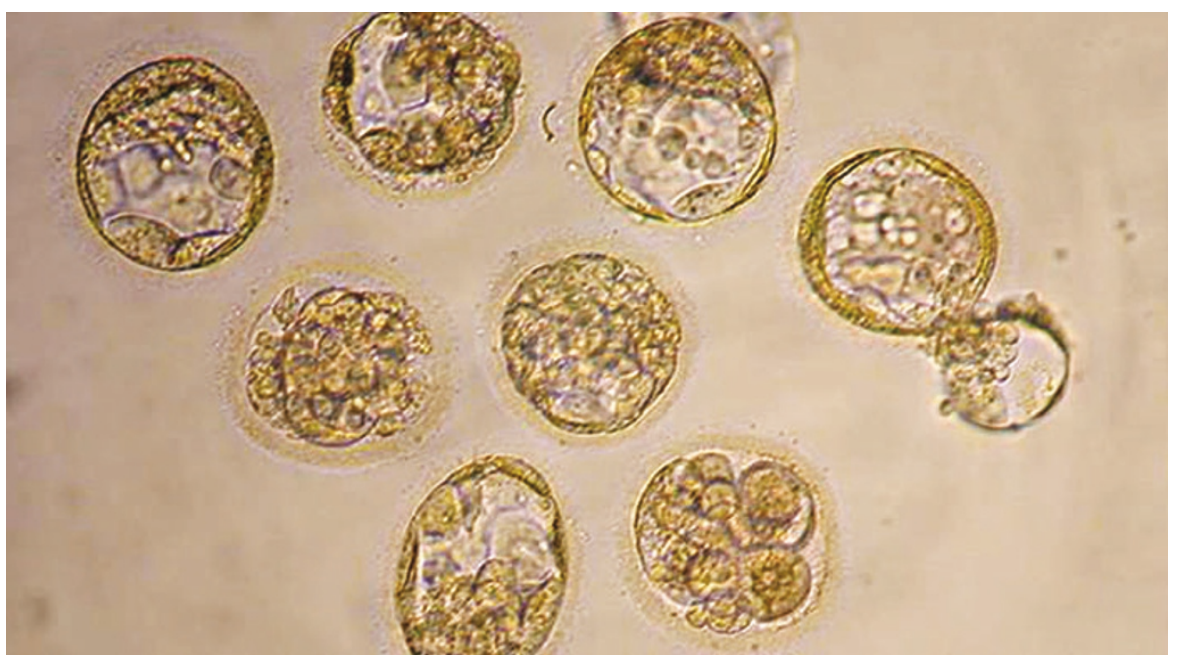

Media attention on these cloned embryos, created this year, has obscured short-term research benefits.

Yet the scientific hurdles that remain are immense. Cloning is tremendously inefficient, for example. When researchers at Seoul National University in South Korea produced the world's first human embryonic stem-cell line from a cloned embryo in February, they got through 242 eggs from 16 women. Until that success rate is improved, cures or treatments from therapeutic cloning will be impossible. "There is a limited number of eggs for all the patients in the world," says Cibelli.

\section{Limited company}

Efficiency may improve with time, although that will require repeat trials with larger numbers of eggs. But sources estimate that fewer than five labs around the world are even trying. The South Korean group has halted its cloning work until a new licensing law comes into effect next January (see Nature 429, 12-14; 2004). Singapore, home to several stem-cell groups, has not yet finalized legislation relating to the licensing of therapeutic cloning.

US law prohibits federal funds from being used for therapeutic cloning, and private labs are not thought to be working on the technique. And in Israel, another country with stem-cell expertise, researchers are discouraged because only a small number of eggs can be used in experiments, says a US scientist who has collaborated with colleagues there.

The Newcastle group faces fewer problems, as researchers there will have access to eggs left over from in vitro fertilization procedures. These number some 2,000 a year, says Alison Murdoch, a reproductive biologist with the group, although the actual number available will depend on how many women give permission for their eggs to be used.

Murdoch and her colleagues will initially attempt to generate a cell line from the cloned embryo of a healthy subject, to make sure the procedure works. Only then will they try to produce a cell line from a patient with diabetes, the clinic's primary disease focus.

Even getting the first healthy cell line will be hard. The South Korean team used adult cell nuclei transferred from cumulus cells surrounding the donor's egg. Using nuclei from the donor avoids problems with mitochondria - energy-producing parts of a cell that carry their own genetic content, which is not always compatible with any mitochondrial DNA found in the donor's egg. Cumulus cells also combine relatively easily with eggs.

The Newcastle group, by contrast, will take nuclei from skin cells and attempt to fuse them with eggs from many different donors. "If we can get the technique to work reliably in the first year we will have made a great deal of progress," says Murdoch. 